\title{
The Role of Intellectual Capital in Increasing Company Value with Profitability as an Intervening Variable
}

\author{
Khairina Natsir ${ }^{1 *}$, Nurainun Bangun ${ }^{1}$ \\ ${ }^{1}$ Faculty of Economics and Business, Universitas Tarumanagara, West Jakarta, 11470, Indonesia \\ *Corresponding author, Email: khairinan@fe.untar.ac.id
}

\begin{abstract}
The company's current value is not only determined by tangible assets. The ability of intangible assets in increasing company value today is very interesting to be studied. Intellectual Capital is an intangible asset in the form of knowledge, talents, skills, information, networking that can be managed by a company to increase its competitive ability. This study investigated the effect of intellectual capital on firm value both directly and indirectly with profitability functioning as an intervening variable. The firm value as a dependent variable is proxied by Tobin's $\mathrm{Q}$, while the profitability variable that functions as an intervening variable is proxied by ROA. Intellectual capital is measured using VAIC, which consists of 3 measurement components, that is Value-Added of Human Capital (VAHU), Value-Added of Employed Capital (VACA), and Structural Capital Value-Added (STVA). The research method used multiple regression analysis tools with a panel data approach and path analysis. The subject of this study is companies that are in the hotel, restaurant, and tourism subsector, which are listed in the Indonesia Stock Exchange in the 2014-2018 period selected using purposive sampling techniques. Research data is in form of secondary data extracted from the company's financial statements during the study period. The results show that profitability, VACA, and VAHU directly affect the value of the company, while only VAHU directly affected the profitability of the company. Meanwhile, in the indirect relationship using the Sobel-Test, the results show that the profitability of the company can only mediate VAHU toward the company value, but profitability cannot mediate the effect of VACA and STVA on company value.
\end{abstract}

Keywords: company value, intellectual capital, profitability, human capital, structure capital, relational capital

\section{INTRODUCTION}

The development of digital business today amazes many people. As an illustration, let's take a look at many start-up companies, whose names had never been heard, but suddenly came to dominate the Indonesian business and were given the title of Unicorn company, especially those engaged in the service businesses, such as Gojek, Tokopedia, Traveloka, Ovo, and Bukalapak. Gojek started its journey in 2010 with its first service, ordering motorcycle taxis through a call center. In December 2018, Gojek's valuation was valued by its investors at IDR 75 trillion, an epic figure for a company that was only established a few years ago [1]. It didn't take long, in April 2019 Gojek officially became the first decacorn start-up company in Indonesia [2]. Decacorn is the term given to digital start-ups with a valuation of more than 10 billion US dollars or the equivalent of IDR 141 trillion. According to a report by the CB Insights research institute in The Global Unicorn Club, Gojek's valuation now is ranked $19^{\text {th }}$ globally [2].
Let's compare it with the company that has been well known in transportation services so far, namely the Garuda Indonesia company. Based on the value of existing shares, the valuation of Garuda Indonesia airline is only IDR 6 trillion. That means that in 2018, Gojek's valuation is 12 times more valuable than Garuda Indonesia, and in 2019 when Gojek was upgraded to Decacorn with a valuation of IDR 141 trillion, Gojek was 23 times ahead of Garuda Indonesia. The question is, how can Gojek's valuation be double of the value of Garuda Indonesia? Meanwhile, Garuda Indonesia's assets are hundreds of Boeing and Airbus planes, while Gojek doesn't have any expensive assets other than just applications that arise from innovation. They have absolutely no massive physical assets. This application is valued dearly, because with the internet the application can reach millions of customers immediately. It's almost no expense at all. Why can it be almost zero-cost? This is because they can develop an intellectual capital to catch their customers with a digital connection, without having to establish thousands of very expensive branch offices. Only with a digital connection, it is 
estimated that currently, Gopay can reach around 30 million subscribers, without branch offices and teller officers.

Valuation means the selling price of a company in the eyes of its investors. In today's digital information era, the success of economic development and increased productivity is determined by innovation and the ability to apply the knowledge. An Economic Institute in Washington, DC, stated that the economic value of the productivity of a company at this time is largely determined by the skills and knowledge of its human resources and the ability of companies to build solutions to problems in business, which in turn will increase the market value of the company [3].

Another industry that is quite important and is currently being developed by the Indonesian government is tourism. The contribution from tourism sector every year continues to increase as shown in the Figure below.

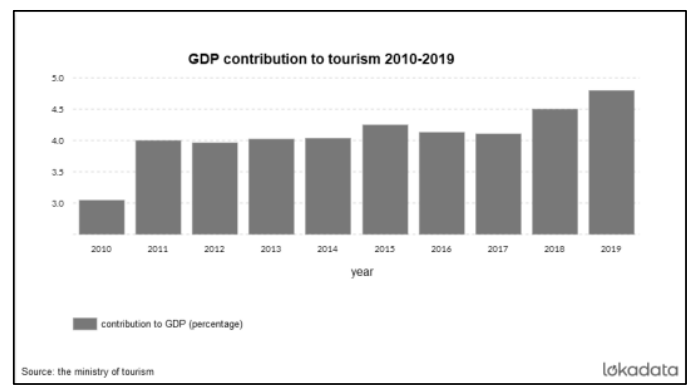

Figure 1 Contribution of tourism to GDP, 2010-2019 Source: [4]

Foreign Exchange Contribution from the tourism sector continues to increase. In 2018, this sector reached IDR 229.5 trillion or an increase of 15.4 percent on an annual basis [5]. The tourism industry, which is a service industry, that operates integrated with the hotel and restaurant industry, is very dynamic and competitive, which requires the ability to continuously adapt to changing customer needs in order to meet customer satisfaction. Service industry connoisseurs today are not only looking for beautiful tourist destination, but also looking for other experiences of the services provided that make them choose hotels and restaurants that can provide the technology-based services that are easily accessible from anywhere. Tourists don't hesitate to spend extra money for a better travel experience. Intellectual capital plays a role in the acquisition cycle of this sub-sector, mainly because most forms of this sub-sector are services that must build intellectual capital expressed in routines, systems, customer databases, networks, etc. which are very important in running hotels effectively in a competitive environment [6].

Companies, that are especially engaged in tourism, must build and maintain all available resources to be able to win a business competition. One of the things that can be developed to achieve a competitive advantage is the intellectual capital. In today's era, whereas global and tight competition occurs, intellectual capital is the company's main advantage.

Intangible assets such as creativity and knowledge have long been trusted by experts as the main capital in inclusive, sustainable, and smart economic and social development.
This is caused by the contribution of intangible assets that drives the potential for economic growth and development that occurs in the context of digital era. So far, in conventional economic thinking, economists have always connected national wealth with the contribution of conventional production factors, such as capital and natural resources [7]. Meanwhile, creativity, knowledge, and, intellectual capital, have no less role in promoting inclusive, smart economic, sustainable, and social development. That is the turning point of economic development advantage from external competitive advantage which is understood to be driven by tangible assets and traditional production factors to become competitive advantage based on internal strength, which is focused on intangible assets and human core competences [8] [9].

There have been many scientific papers that have been disseminated about intellectual capital and company performance. The research conducted by [10] provides an empirical evidence that investors tend to give higher valuations to companies with better intellectual capital efficiency, and those companies with good intellectual capital efficiency will get better profits, greater revenue growth, and getting better in the current year and the following years.

Other previous studies showed that intellectual capital affected company value positively as measured by stock prices [11]. In other studies, intellectual capital can improve a company's financial performance (profitability) [11] - [13] The research conducted by [14] revealed that intellectual capital can be considered as a relevant appraiser with a significant relationship with the market value of a security, meaning that intellectual capital affects firm value.

The findings from previous research showed the results, whereas intellectual capital and company value have a causal relationship, with the same phenomenon applies to intellectual_capital and profitability. Based on the previous study, profitability can function as an intervening variable in the effect of intellectual capital on firm value. At the time of this research, there were not many previous studies investigating the significance of profitability in mediating between firm value and intellectual capital. In the research conducted by Nuryaman [15], it was found that intellectual capital has a positive effect on firm value, as well as intellectual capital has a positive effect on profitability, and this research also shows that profitability can mediate the effect of intellectual capital on firm value [15].

The purpose of this study was to investigate the empirical evidence regarding the effect of intellectual capital on the value of the hotel, restaurant, and tourism sub-sector companies listed in the Indonesia Stock Exchange (IDX) with profitability as an intervening variable.

\section{THEORETICAL BACKGROUND}

\subsection{Company Value}

Company value is an assessment given by investors, which is the fair value of the company that reflects the investors' perceptions of certain issuers, which in turn are always related to stock prices [16]. The company value is also 
defined as the selling price of the company that is considered adequate by potential investors when the company is liquidated [17]. In associated with the context of intellectual capital, the definition of company value is a reflection of the achievement of performance in operating the company from the time it was founded until now [18]. Investors who consider that a company has good prospects in the future tend to buy shares of the company. As a result, there is a high demand for a share, which causes the share price to increase due to high valuation by investors toward the company.

According to [19], there are several methods are used to measure the company value in market valuation, which consists of price-earning ratio (PER), book-value ratio (PBV), market-to-book ratio (MBR), dividend-yield ratio, and dividend-payout ratio. (DPR). The measuring instrument for company value used in this study is Tobin's $Q$, because Tobin's Q takes into account all components of the company's debt and share capital, not limited to ordinary shares and company equity, but all company assets, including the tangibles and intangible assets. A large Tobin's Q value indicates that the company has good growth prospects. This is because the market value of the company's assets is higher than its book value, indicating the willingness of investors to make greater sacrifices to own the company [20]. Tobin's Q can be formulated as a comparison of the market value of an asset with the estimated amount of money that must be spent to replace all these assets at this time.

\subsection{Intellectual Capital}

Wiederhold [21] defined intellectual capital as intangible knowledge that can be converted into value. [8] recommended that intellectual capital should be managed sustainably. Therefore, it is necessary to design programs for the management of intellectual capital regularly. ValueAdded Intellectual Coefficient (VAIC) is a technique pioneered by Pulic in 2000 who built a way to measure the efficiency of value formation in accounting-based companies. Intellectual capital can be in the form of synergy between knowledge, information, experiences possessed by employees, market share, and collaboration with parties related to the company [15]. Intellectual capital can be managed and renewed to achieve sustainable prosperity [8]. Intellectual Capital is classified as Human Capital, Structure Capital, and Relational Capital. Human Capital is the value provided by employees in business through the application of skills and expertise [22]. According to [23], the attributes of human capital consist of knowledge, education, level of qualification, skills, talent, work-related competencies, innovativeness, proactiveness, entrepreneurial spirit, professionalism, and experience. Structure Capital is a nonphysical infrastructure that supports organizational processes and databases, that enable human capital to function [22]. Structure Capital includes processes, patents, and trademarks, as well as the image of the organization, organizational information systems and software, and company-owned databases. Meanwhile, Relational Capital includes the elements such as customer relationships, supplier relationships, trademarks, and trade names (which are only valued based on the customer relationship) licenses, and franchises.

\subsection{Profitability}

Profitability is the main goal expected by a company, when the total amount of revenue obtained from business activities exceeds the expenses, costs, and taxes [24]. [25] stated the definition of profitability as the relationship between income and costs generated by using company assets both currently and still in productive activities.

The Profitability ratio is a ratio used in assessing the company's ability to earn profit. This ratio is also used as an indicator in measuring the level of effectiveness achieved by management. This ratio is the first thing potential investors or shareholders pay attention to and is associated with the share price and dividends they will receive.

\subsection{Research Hypothesis}

\subsubsection{Linkage of intellectual capital and company- value}

Based on the classification, company resources covered by Intellectual Capital are described above, namely Human Capital, Structural Capital, and Relational Capital [8]. If the company is concerned about the management of these three resources, it is believed that the company will increase in value. The explanations are as follows:

a. Human Capital includes human resources who have the knowledge, education, talent, skills, and all other advantages. Continuous coaching and management of employees will increase employees' competence and motivation. The bright ideas of employees are very likely to make the company richer in product and intellectual property, and is able to compete in the business world. Investors in the capital market are interested in appreciating the values that can be developed through good competence for the excellence of the company's intellectual capital by increasing the shares of these companies and will have an impact on the increase in company value.

$\mathrm{H}_{1}$ : Human Capital has a positive effect on company value.

b. Structure Capital includes processes, patents, and trademarks, as well as organizational image, information systems, and company-owned software, and databases. All these resources support the company in its smooth operations. The infrastructure available in the company, if being managed properly, will be able to smoothen the business processes that occur. The existence of patents, copyrights, trademarks and, so on will make investors confident in the intellectual capabilities of the company, and the effect is that investors will have more confidence in the capabilities that the company has achieved. 
Investor confidence has an impact on increasing company value.

$\mathrm{H}_{2}$ : Structure Capital has a positive effect on company value.

c. Relational Capital (Capital Employed) concerns the company's ability to collaborate with customers, investors, suppliers, and other related companies. It means that this company cares about the interests and satisfaction of customers, can maintain the quality and quantity of production, and is always connected with shareholders. These kinds of things can make the company have a good image in the eyes of investors and have an impact on high company value. Capital employed efficiency is all tangible values contained in the company's relationship with its external environment (clients, distributors, suppliers, investors) and what has been stated, for agencies, through rewards and reputation between clients, labor union relations, and the concluded trust and agreement that this element has is a component of intellectual capital that provides tangible value and arises from various parts outside the company environment that can add value to the company [26].

$\mathrm{H}_{3}$ : Relational Capital has a positive effect on company value.

\subsubsection{Linkage of Intellectual Capital with Profitability}

Intellectual capital will affect the company's financial performance. Companies that have human resources with the ability, competence, and high commitment will certainly result in a high and efficient level of productivity, both personally and as a team. This situation will have a good influence on the company, in which the company will be able to produce quality products and earn profits. Structure capital reflects the ability of the company's systems, structure, strategy, and culture to meet market demands and achieve organizational goals. If a company has a good capital structure, it will certainly make it easier to achieve the company targets, including company profitability. Previous research has proven that intellectual capital has a positive effect on profitability [13] [27]. The same thing is shown by [13], who found that Korean companies engaged in manufacturing sector, that can maintain the efficiency of intellectual capital, can achieve greater profitability and higher sustainable growth.

$\mathrm{H}_{4}$ : Human Capital effects profitability positively.

$\mathrm{H}_{5}$ : Structure Capital effects profitability positively.

$\mathrm{H}_{6}$ : Relational Capital effects profitability positively.

\subsubsection{Linkage of Profitability with Firm Value}

An increase in profitability indicates an increase in the company's capability to achieve profit for the benefit of shareholders. The increased profit reflects the company's capability in paying dividends so that investors will provide a plus for the company, which will increase the company's value in the eyes of investors. Profitability is the biggest attraction for company owners because profit is a form of the performance of the company's management on the funds invested by shareholders. According to research results by Natsir et al., [28], profitability has a positive effect on the value of manufacturing companies.

$\mathrm{H}_{7}$ : Profitability affects Companies Value positively.

\subsubsection{Profitability as an intervening variable}

From the explanation above, it has been explained that intellectual capital affects the company's financial performance. Companies that have employees with high competence, are committed to certainly result in a high and efficient level of productivity, both personally and as a team. This situation will have a good influence on the company, whereas the company will be able to generate quality products and earn profits. Structure capital reflects the ability of the company's systems, structure, strategy, and culture to meet market demands and achieve organizational goals. If the company has a good capital structure, it will certainly make it easier to achieve its targets, including company profitability. From this description, it can be seen that profitability can increase because of the intellectual ability or knowledge (intellectual capital), which can accelerate the achievement of profits by optimizing all available company resources. With the company's ability to accelerate and increase profits, the company's image will increase in the eyes of investors so that the company's value will increase as well. Relational Capital (Capital Employed) is the company's seriousness in the quality and quantity of products and attention in building collaboration with customers, investors, suppliers, and other related companies. Good relations with partners can accelerate the increase in sales and company profitability. When the company's profitability is good, the company's image will be good in the eyes of investors, so that the company's value is also good.

$\mathrm{H}_{8}$ : Profitability can mediate the effect of human capital on firm value.

$\mathrm{H}_{9}$ : Profitability can mediate the effect of Structure Capital on firm value.

$\mathrm{H}_{10}$ : Profitability can mediate the effect of Relational Capital on firm value.

\section{RESEARCH METHOD}

\subsection{Population and Sample}

Indonesia's strategic geographical position makes its nature so beautiful. The tourism sector is important, because it can increase economic growth, create jobs, reduce poverty, and promote tolerance. The growth of tourism sector which continues to increase every year as seen in Figure 1, is quite 
interesting to be studied. So, we were interested to take the hotel, restaurant and tourism sub-sector companies as research subjects. The population scope is the hotel, restaurant, and tourism sub-sector companies listed in the IDX for the 2014-2018 period. The product of this sector is service. Hotels and restaurants as a transit point for tourists, must be comfortable and meet the values set by customers. A hotel, restaurant, and tourist attraction is not only good in terms of infrastructure, but must be equipped with innovation and technological and cultural values, all of which are the components of intellectual capital.

The sample was selected by purposive sampling technique, where the criteria for sampling are:

a. Hotel, Restaurant, and Tourism sub-sector companies listed in the IDX for the 2014-2018 period.

b. The companies published their financial reports in the financial year ending every December 31 each year during the 2014-2018 period.

c. The companies provided all the information needed in this study during the 2014-2018 period.

\subsection{Operationalization of Variables}

The dependent variables here are firm value and profitability. The measurements for the two dependent variables are as follows:

1. The firm value variable is proxied by Tobin's $Q$, with the following formula:

Tobin's Q = (Total Market Value + Total Book Value of Liabilities) / Total Book Value of Assets [29].

The profitability is measured by Return on Assets with the following formula:

$R O A=\frac{\text { Net Income }}{\text { Total Assets }} \quad$ [30]

2. The independent variable of intellectual capital is measured by the three components of Value Added Intellectual Capital, namely VACA, VAHU and STVA as developed by Pulic in 1998 [31] with the following steps: $\mathrm{VA}=\mathrm{OUT}-\mathrm{IN}, \mathrm{VACA}=\frac{\mathrm{VA}}{\mathrm{CE}}, \mathrm{VAHU}=\frac{\mathrm{VA}}{\mathrm{HC}}, \mathrm{STVA}=\frac{\mathrm{SC}}{\mathrm{VA}}$ Whereas:

- VA: Value Added, Out = Total Sales and other income, IN: Cost of production outside of employee expenses.

- CE: Capital Employed is available capital (equity and net profit)

- SC: Structural Capital = VA - HC

- HC: Human Capital (employee expense)

\subsection{Data Analysis}

\subsubsection{Multiple Linear Regression Analysis}

Panel data is a combination of time-series and cross-sectional data [32]. Three multiple regression methods were used to analyze panel data, which are as follows: a. Pooled Least Square (PLS) or Common Effect (CE). The equation for the Pooling Lease Square is formulated as follow:

$$
Y_{\text {it }}=\alpha_{0}+\beta_{1} X_{1 \text { it }}+\beta_{2} X_{2 i t}+\beta_{3} X_{3 i t}+\ldots+\beta_{n} X_{\text {nit }}+\varepsilon_{\text {it }}
$$

b. Fixed Effect (FE). The model equation is notated as follow:

$$
Y_{\text {it }}=\alpha_{1}+\alpha_{2} D_{2}+\ldots+\alpha_{n} D_{n}+\beta_{1} X_{1 i t}+\ldots+\beta_{n} X_{n i t}+\varepsilon_{i t}
$$

c. Random Effect (RE) model. The model equation can be written with the following formula:

$$
Y_{\text {it }}=\alpha_{0}+\beta_{1} X_{1 i t}+\ldots+\beta_{n} X_{\text {nit }}+\varepsilon_{\text {it }}+\mu_{\text {it }}
$$

The selection of the best model was conducted by the ChowTest, the Housman-Test, and the Lagrange Multiplier-Test.

Hypothesis testing was carried out as follows:

a. A t-test is conducted to establish the partial effect of independent variables on the dependent variable.

b. The coefficient of determination $\left(\mathrm{R}^{2}\right)$ is a technique for measuring how much the independent variable contributes in explaining the dependent variable.

\subsubsection{Path Analysis with Sobel Test}

Path analysis produces a model that shows a causal mechanism in which the independent variable produces direct and indirect effects on the dependent variable [33]. Statistically, the Sobel Test is a method for testing the significance of the mediating effect. The Sobel Test uses the magnitude of the indirect effect compared to the estimated standard measurement error to obtain the t-statistics [34].

$t=\frac{\left(\tau-\tau^{\prime}\right)}{S E}$ or $t=\frac{(\alpha \beta)}{S E}$, whereas: $\mathrm{SE}$ is the combined standard error calculated by the formula:

$S E=\sqrt{\alpha^{2} \sigma_{\beta}^{2}+\beta^{2} \sigma_{\alpha}^{2}}$, while $\sigma_{\beta}^{2}$ is a variant of $\beta$ dan $\sigma_{\alpha}^{2}$ is a variant of $\alpha$.

\section{RESULTS AND DISCUSSIONS}

\subsection{The Description of Research Subjects}

The population is the hotel, restaurant, and tourism sub-sector companies listed in the IDX for the period 2014-2018, which were taken by purposive sampling technique. Based on the predetermined sample selection criteria, 20 companies were selected as samples in this study.

\subsection{The Description of Research Objects}

The objects examined in this research consist of Value-Added Capital Employed (VACA), Value-Added Human Capital (VAHU), Structural Capital Value-Added (STVA) as a component of Value-Added Intellectual Capital (VAIC), Profitability (ROA) and Firm Value (Tobin's Q). This study uses secondary data obtained from the annual reports of 
sample companies during the 2014-2018 period sourced from the official website of the IDX, namely: www.idx.co.id, www.sahamok.com, finance.yahoo.com. and company website.

\subsection{Multicollinearity Test Results}

The result of the multicollinearity test toward the independent variables of VACA, VAHU, STVA, and Profitability (ROA), show that they do not experience multicollinearity since all the correlations are less than 0.8 .

\subsection{Multiple Regression Analysis}

To determine the best regression approach, the Chow, Houseman, and Lagrange Multiplier tests were performed consecutively. The level of confidence used by the researcher is $\alpha=5 \%$. Based on tests that have been carried out using the Eviews 9 software, the test results are shown in the following table:

Table 1 The selection of the best regression model

\begin{tabular}{lllll}
\hline Test & $\begin{array}{l}\text { Model } \\
\text { Selection }\end{array}$ & Hipothesis & $\begin{array}{l}\text { Test Result } \\
\text { (Prob) }\end{array}$ & $\begin{array}{l}\text { Selected } \\
\text { Model }\end{array}$ \\
\hline Chow & CE vs FE & $\begin{array}{l}\mathrm{H}_{0}: \mathrm{CE} \\
\mathrm{H}_{1}: \mathrm{FE}\end{array}$ & 0.0000 & $\begin{array}{l}\text { Fixed } \\
\text { effect }\end{array}$ \\
& FE vs RE & $\begin{array}{l}\mathrm{H}_{0}: \mathrm{RE} \\
\mathrm{H}_{1}: \mathrm{FE}\end{array}$ & 0.3650 & $\begin{array}{l}\text { Random } \\
\text { Effect } \\
\text { Houseman }\end{array}$ \\
& \multirow{2}{*}{ RE vs CE } & $\begin{array}{l}\mathrm{H}_{0}: \mathrm{CE} \\
\mathrm{H}_{1}: \mathrm{RE}\end{array}$ & 0.0000 & $\begin{array}{l}\text { Random } \\
\text { Effect }\end{array}$ \\
\hline
\end{tabular}

Based on the test results from the table above, the Random Effect is the best regression estimate.

Multiple regression using random effect model is used to determine the effect of the independent variables on the dependent variable.

In this study, 2 (two) models were built, namely:

a. Model 1 (one) is the independent variable of ValueAdded Capital Employed (VACA), Value-Added Human Capital (VAHU), Structural Capital Value-Added (STVA), and Profitability (ROA) regressed to firm value (Tobin's Q).

b. Model 2 (two) is the independent variable of ValueAdded Capital Employed (VACA), Value-Added Human Capital (VAHU), Structural Capital Value-Added (STVA) that were regressed against the intervening Profitability variable (ROA).

The hypothesis test was conducted using t-test. The result are as follows:
Table 2 The Summary of t-Test Results

\begin{tabular}{ccccccl}
\hline Endogen & \multicolumn{2}{c}{ Exogenous Coefficient Std. Error } & t-Statistic & Prob. & \multicolumn{1}{c}{ Result } \\
\hline & C & -0.508979 & 4.449297 & -0.114395 & 0.9092 & \\
& ROA & -3.049087 & 0.747027 & -4.081629 & 0.0001 & significant \\
Firm Value & VACA & -60.38812 & 10.11443 & -5.970489 & 0.0000 & significant \\
(Tobin's Q) & STVA & 0.728646 & 1.424201 & 0.511618 & 0.6104 & insignificant \\
& VAHU & 7.692081 & 0.220261 & 34.92264 & 0.0000 & significant \\
\hline & C & 2.701028 & 0.104733 & 25.78958 & 0.0000 & \\
Profitability & VACA & 0.065382 & 0.255680 & 0.255717 & 0.7989 & insignificant \\
(ROA) & STVA & 0.068484 & 0.038850 & 1.762778 & 0.0821 & insignificant \\
& VAHU & 0.003526 & 0.001407 & 2.506217 & 0.0144 & significant \\
\hline
\end{tabular}

The regression model one and model two are as follows: $\mathrm{ROA}=2.701028+0.065382 * \mathrm{VACA}+0.068484 * \mathrm{STVA}+$ $0.003526 * \mathrm{VAHU}+\mathrm{e}$

TOBIN'S Q $=-0.508979-3.049087 * \mathrm{ROA}-60.38812 * \mathrm{VACA}+$ $0.728646 *$ STVA $+7.692081 * \mathrm{VAHU}+\mathrm{e}$

The following is a path diagram of the structural equation and its coefficients:

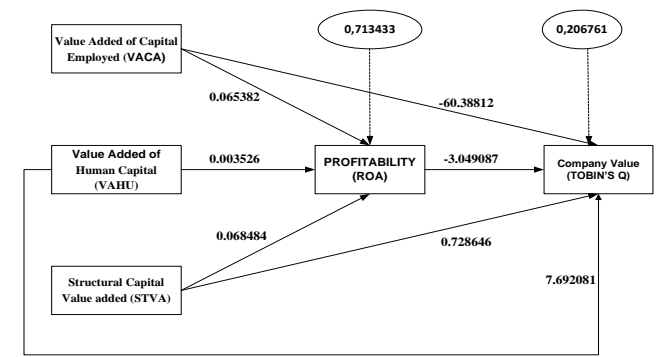

Figure 2 Path Coefficients of Research Model

The calculation result of the total effect of intellectual capital on firm value for each path are as follows:

Table 3 The Influence of IC on Firm Value

\begin{tabular}{llll}
\hline & $\begin{array}{l}\text { Direct } \\
\text { effect }\end{array}$ & $\begin{array}{l}\text { Indirect effect } \\
(\text { Throuh ROA) }\end{array}$ & $\begin{array}{l}\text { Totoal } \\
\text { Effect }\end{array}$ \\
\hline VACA $\rightarrow$ TOBIN'S Q & -60.38812 & $-0,1993554$ & $-60,5874754$ \\
VAHU $\rightarrow$ TOBIN'S Q & 7.692081 & $0 .-0,0107511$ & 7,6813299 \\
STVA $\rightarrow$ TOBIN'S Q & 0.728646 & $-0,2088137$ & 0,5198323 \\
\hline
\end{tabular}

\subsection{The Mediation-Effect Test Results}

In this study, there is a mediating variable that is proxied by profitability. The Sobel Test was carried out by testing the strength of the indirect effect of Capital-Employed ValueAdded (VACA), Human-Capital Value-Added (VAHU), Structural-Capital Value-Added (STVA) on firm value (Tobin's Q) through the profitability as a mediating variable (ROA), as calculated by multiplying paths:
$\mathrm{VACA} \rightarrow \mathrm{ROA} \quad=0.065382$
(a)
ROA $\rightarrow$ Tobin's $Q=-3.049087$
$\mathrm{VAHU} \rightarrow \mathrm{ROA} \quad=0.003526$
ROA $\rightarrow$ Tobin's $Q=3.049087$
STVA $\rightarrow$ ROA $=0.068484$
ROA $\rightarrow$ Tobin's $Q=-3.049087$
(e)
(f) 
The combined standard error for each path was calculated and the result are as follows:

a. Path 1 compound standard error : $\mathrm{S}_{\mathrm{ab}}=0.804131798$

b. Path 2 compound standard error: $S_{c d}=0.005142708$

c. Path 3 compound standard error : $S_{e f}=0.1322559$

To test the significance of the indirect effect, the t-statistics values of the coefficients ab, cd, and ef were calculated with the following results:
a. Path $1: t=0.026920691$
b. Path $2: t=2.090548552$
c. Path $3: t=-1.578860936$

To determine the significant effect of the mediating variable on each pathway, the t-statistical results that have been shown above are compared with the t-table statistics at $\alpha=5 \%$ and $\mathrm{df}=95$, which is 1.98 . The results of the significance of the Sobel Test are presented in the following table:

Table 4 Sobel Test Results

\begin{tabular}{|c|c|c|c|c|}
\hline & Indirect effect & $\begin{array}{l}\text { SE of indirect } \\
\text { effect }\end{array}$ & t_statistic & Result \\
\hline Path 1 & $\begin{array}{l}\text { VACA } \rightarrow \text { ROA }=0.065382 \\
\text { ROA } \rightarrow \text { Tobin's } Q=-3.049087\end{array}$ & $s_{a b}=0,804131798$ & $\mathrm{t}=\frac{\mathrm{ab}}{\mathrm{sab}}=0,026920691$ & insignificant \\
\hline Path 2 & $\begin{array}{l}\text { VAHU } \rightarrow \text { ROA }=-0.003526 \\
\text { ROA } \rightarrow \text { Tobin's } Q=-3.049087\end{array}$ & $s_{c d}=0,005142708$ & $\mathrm{t}=\frac{\mathrm{cd}}{\mathrm{scd}}=2,090548552$ & significant \\
\hline Path 3 & $\begin{array}{l}\text { STVA } \rightarrow \text { ROA }=0.068484 \\
\text { ROA } \rightarrow \text { Tobin's } Q=3.049087\end{array}$ & $s_{e f}=0,1322559$ & $\mathrm{t}=\frac{\mathrm{ef}}{\mathrm{sef}}=-1,578860936$ & insignificant \\
\hline
\end{tabular}

\subsection{The Goodness-of-Fit Model Test Results}

The test results on the coefficient of determination Equation model 1 shows an Adjusted R-squared value of 0.49. This means that the Profitability (ROA) can be explained as much as $49 \%$ by VACA, VAHU, and STVA, and the remaining $51 \%$ is explained by other factors outside the model used. Meanwhile, the adjusted R-Squared of model 2 give the result as 0.957250 . This means that the firm value (which is proxied by Tobins's Q) can be explained by VACA, VAHU, STVA, and ROA as much as $95.7 \%$, and the remaining $4.3 \%$ is explained by other factors outside the model used.

\subsection{Discussions}

a. Analysis of the direct effect of intellectual capital on the profitability variable (ROA)

Based on the results of the t-test in measuring the direct effect of intellectual capital on profitability as shown in Table 2, it can be seen that from the three variables used to measure intellectual capital, namely VACA, STVA, and VAHU of the hotel, restaurant, and tourism subsector companies being observed, only VAHU has a significant impact on ROA. This means that the contribution of each unit Capital Employed to valueadded (VACA) and Structure Capital in creating value (STAVA) has not been able to increase the profitability achieved by the company. The intellectual property, brand, infrastructure assets have not been utilized optimally by the respondent companies to increase profits. The existence of patents, copy-rights, trademarks, and so on cannot be used by companies to gain profit. However, the results of the study show that VAHU has a significant and positive effect on profitability. This means that every cent spent on labor (Human Capital) can increase profitability. Continuous coaching and management of employees can increase employee competence and motivation. High competence and motivation of an HR will be able to facilitate the company to excel in business competition. The bright ideas of the employees are very likely to make the company richer in product and intellectual property and able to compete in the business world, which in turn can increase the company's profitability. The findings of this study indicate that the more efficient the company manages the intellectual resources of human capital owned by the company, it will provide increased results as shown by the increase in the company's financial performance [35].

b. Analysis of the direct effect of intellectual capital on Firm Value variables.

Based on the results of the t-statistical test in measuring the direct effect of intellectual capital on Firm Value (Tobin's Q) as shown in Table 2, it can be seen that of the four variables investigated from the hotel, restaurant, and tourism sub-sector companies, namely VACA, STVA, and VAHU. and Profitability (ROA), there are three variables, namely ROA, VACA, and VAHU which significantly affect Tobin's Q, while the STVA variable does not affect firm value. VACA negatively affects firm value. This can happen, because the companes has not been able to improve their image so that investors have not shown an interest in investing. VAHU effects firm value significantly and positively. Human Capital includes human resources or company employees, who have knowledge, education, talent, skills, and all other advantages. Investors will show their appreciation to the values that can be developed through good competence for the advantages of the company's intellectual capital through an increase in the shares of these companies and will give an effect of increase in the value of the company. The statistical results are displayed in Table 2. It also shows that profitability has a positive effect on firm value. This clearly illustrates that investors will be interested in investing in companies that can generate profits or have high profitability. Therefore, intellectual capital needs to be managed optimally to encourage company performance. If the company's performance is good, investors will be more confident in investing in the company, so that the company's market value will also be pushed-up [36].

c. Analysis of the Effect of Mediating Variable

Based on the results of statistical tests using the Sobel Test as shown in Table 4, it can be seen that profitability is not significant in mediating the effect of VACA on firm value (Tobin's Q). Profitability is also not able to mediate the effects of STVA on the company (Tobin's Q). But 
from this single test, the results show that profitability can mediate VAHU in influencing the company (Tobin's Q). The results of hypothesis testing indicate that the hypothesis was accepted. The test results show that VAHU through ROA has a significant effect on Tobin's $\mathrm{Q}$ in a positive direction. The path t-statistics value obtained is 2.0905 (> 1.98). This result is also supported by testing the first hypothesis so that the higher the value of VAHU will affect the company's performance, thereby encouraging an increase in ROA. This condition will get a positive response from investors so that it can increase company value (Tobin's Q) through its share price. Such conditions will receive positive appreciation by investors so that the company's stock price will also increase. The increase in share price will increase Tobin's Q. Market Participants provide a higher assessment for companies with high financial performance. Good financial performance will provide a positive response to the market, thereby increasing company value. [35].

\section{CONCLUSIONS}

Based on a series of statistical tests and the discussion that has been carried-out above, it can be concluded as follows:

1. Value-Added Capital Employed (VACA) has a significant negative effect directly on firm value.

2. Value-Added Human Capital (VAHU) has a significant positive effect directly on firm value.

3. Structural Capital Value-Added (STVA) has no significant effect on company value.

4. Profitability (ROA) has a significant positive effect on firm value.

5. Value-Added Capital Employed (VACA) has no significant effect on Profitability (ROA).

6. Value-Added Human Capital (VAHU) has a significant and positive effect on Profitability (ROA).

7. Structural Capital Value-Added (STVA) has no significant effect on profitability (ROA).

8. Profitability can not mediate the effect of Value-Added Capital Employed (VACA) on company value.

9. Profitability can mediate the effect of Value-Added Human Capital (VAHU) on company value.

10. Profitability can not intervene Structural Capital Value Added (STVA) on company value.

This study only classified the components of intellectual capital into three kinds so that other components of intellectual capital that are members of intellectual property were not included. The useful suggestion that can be provided is that future researchers should consider using the methods of measuring intellectual capital in addition to the VAIC method. Other classifications of intellectual capital can be used to obtain a comprehensive picture of intellectual capital. For further researchers, it is recommended to add the indicators to estimate the company performance and market value in order to obtain maximum results such as cash ratio for company performance and Dividend-Payout Ratio (DPR) for market value.

\section{REFERENCES}

[1] Y. Antariksa, "Kenapa Valuasi Gojek 12x Lebih tinggi Dibanding Garuda Indonesia?," Strategi

Manajemen, 2018.

[2] CBN Insights, "The Global Unicorn Club," $C B N$ Insights, 2020. [Online]. Available:

https://www.cbinsights.com/research-unicorn-companies. [Accessed: 13-Sep-2020].

[3] V. T. Akpinar and A. Akdemir, "Intellectual capital," in Conference: First International Joint Symposium on Business Administration "Challenges for Business Administrators", 2000, vol. 82, no. 9, pp. 721-722.

[4] Kementerian Pariwisata, "Kontribusi pariwisata terhadap PDB, 2010-2019," Lokadata.beritagar.id, 2020. [Online]. Available:

https://lokadata.beritagar.id/chart/preview/kontribusipariwisata-terhadap-pdb-2010-2019-1582001327.

[5] CNN Indonesia, "Menghitung Kontribusi Sektor Pariwisata Bagi Ekonomi RI," CNN Indonesia, Rabu, 26/02/2020, 2020. [Online]. Available:

https://www.cnnindonesia.com/ekonomi/2020022612131 4-532-478265/menghitung-kontribusi-sektor-pariwisatabagi-ekonomi-ri. [Accessed: 04-Oct-2020].

[6] T. E. j. Engström, P. Westnes, and S. Furdal Westnes, "Evaluating intellectual capital in the hotel industry," Journal of Intellectual Capital, vol. 4, no. 3, pp. 287303, 2003.

[7] B. L. Edvinsson, Intellectual Capital for Communities Edited by Ahmed, vol. February 1, no. 12. 2007.

[8] F. Matos, V. Vairinhos, P. Maurício, and S. Leif, Intellectual Capital Management as a Driver of Sustainability. 2019.

[9] A. E. H. Abd-Elrahman, A. A. E. El-Borsaly, E. A. E. Hafez, and S. A. Hassan, "Intellectual Capital and Service Quality Within the Mobile Telecommunications Sector of Egypt," Journal of Intellectual Capital, no. 2009, 2020.

[10] M. C. Chen, S. J. Cheng, and Y. Hwang, “An empirical investigation of the relationship between intellectual capital and firms' market value and financial 
performance," Journal of Intellectual Capital, vol. 6, no. 2, pp. 159-176, 2005.

[11] A. et al Poraghajan, "Impact of Intellectual Capital on Market Value and Firms' Financial Performance: Evidences from Teheran Stock Exchange," World of Sciences Journal, vol. 1, no. 12, 2013.

[12] W. S. Nugroho and G. Gudono, "The Significance Key of Intellectual Capital To Increase Financial Performance, Firm's Growth, and Market Value," The Indonesian Journal of Accounting Research, vol. 21, no. 2, pp. 269-290, 2018.

[13] R. Afroze, "Intellectual Capital and Its influence on the Financial Performance," ASA University Review, vol. 5, no. 1, pp. 161-173, 2011.

[14] G. Özer and İ. Çam, "The Role of Human Capital in Firm Valuation: An Application on BIST," in Procedia Social and Behavioral Sciences -12th International Strategic Management Conference, ISMC 2016, 28-30 October 2016, Antalya, Turkey, 2016, vol. 235, no. October, pp. 168-177.

[15] Nuryaman, “The Influence of Intellectual Capital on The Firm's Value with The Financial Performance as Intervening Variable," vol. 211, no. September, pp. 292 298, 2015.

[16] O. Languju, M. Mangantar, and H. H. Tasik, "Pengaruh Return on Equity, Ukuran Perusahaan, Price Earning Ratio dan Struktur Modal terhadap Nilai Perusahaan Property and Real Estate Terdaftar Di Bursa Efek Indonesia," Jurnal Berkala Ilmiah Efisiensi, vol. 16, no. 02, pp. 387-398, 2016.

[17] A. D. Rahmawati, Topowijono, and S. Sulasmiyati, "Pengaruh Ukuran Perusahaan, Profitabilitas, Struktur Modal, dan Keputusan Investasi Terhadap Nilai Perusahaan (Studi pada Perusahaan Sektor Properti, Real Estate, dan Building Construction yang Terdaftar di Bursa Efek Indonesia (BEI) Periode 2010-2011)," Jurnal Administrasi Bisnis, vol. 23, no. 2, p. 7, 2015.

[18] R. Nugraha, "Analysis of the Influence of Capital Labour Intensive,Investment, Managerial Ownership, Operating Leveragethrough Dividend and Financial Leverage As Intervening Variable on Firm Value in Indonesia Non Financial Sector Companies," JRMSI Jurnal Riset Manajemen Sains Indonesia, vol. 7, no. 1, p. $1,2016$.

[19] E. F. Brigham and J. F. Houston, Fundamentals of Financial Management, 5 edition. Boston, MA 02210:
Cengage Learning, 2019

[20] W. I. Permanasari, "Pengaruh Kepemilikan Manajemen, Kepemilikan Institusional dan Corporate Social Responsibility Terhadap Nilai Perusahaan," Universitas Diponegoro, 2010.

[21] G. Wiederhold, Valuing Intellectual Capital: Multinationals and Taxhavens. Springer

Science+Business Media, 2014.

[22] J. Maddocks and M. Beaney, "See the invisible and intangible," Knowledge Management, vol. 16, no. March, 2002.

[23] C. J. Cronje and S. Moolman, "Intellectual Capital : Measurement, Research method Research problem," vol. 16, no. 1, 2013.

[24] A. N. Nasimi, "Effect of Capital Structure on Firm Profitability (An Empirical Evidence from London, UK)," vol. 16, no. 4, 2016.

[25] T. M. Deitiana and Robin, "The Effect of Firm Size, Profitability, Tangibility, Non-Debt Tax Shield and Growth to Capital Structure on Banking Firms Listed in Indonesia Stock Exchange from 2007 - 2012," South East Asia Journal of Contemporary Business, Economics and Law, vol. 10, no. 1, pp. 37-44, 2016.

[26] Haldami, F. Bella, Martiningtiyas, and C. Rahayu, "Pengaruh Intellectual Capital terhadap Kinerja Perusahaan pada Industri Otomotif, Metal dan Allied, serta Chemical yang terdaftar di Bursa Efek Indonesia (BEI). EJurnal Manajemen Fakultas Ekonomi Universitas Trisakti.”, EJurnal Manajemen Fakultas Ekonomi Universitas Trisakti. Vol. 1, vol. 1, 2014.

[27] F. Sardo, Z. Serrasqueiro, and H. Alves, "On the relationship between intellectual capital and financial performance: A panel data analysis on SME hotels," International Journal of Hospitality Management, vol. 75, no. July 2017, pp. 67-74, 2018.

[28] K. Natsir, Yusbardini, and N. Bangun, "FaktorFaktor yang Mempengaruhi Nilai Perusahaan Manufaktur di Bursa Efek Indonesia,” Jakarta, 2019.

[29] Edu\$saham.com, "Pengertian Tobin's Q, Cara Mengukur, Kekurangan dan Kelebihan,” 2019. [Online]. Available:

https://www.edusaham.com/2019/03/pengertian-tobinsq-beserta-rumus-cara-mengukur-kekurangan-dankelebihan.html. [Accessed: 31-Aug-2019].

[30] T. Hery Tri Admojo, Analisis Laporan Keuangan : 
Pendekatan Rasio Keuangan. Yogyakarta: CAPS, 2015.

[31] A. Pulic, "Measuring the performance of intellectual potential in knowledge economy," in 2nd World

Congress of Measuring and Managing Intellectual Capital, 1998.

[32] P. N. Vijayamohanan, "Panel Data Analysis Lecture Notes," Time, no. 1968, pp. 1-6, 2017.

[33] A. Crossman, "Understanding Path Analysis," 2019. [Online]. Available: https://www.thoughtco.com/pathanalysis-3026444. [Accessed: 31-Aug-2019].

[34] M. E. Sobel, "Asymptotic Confidence Intervals for Indirect Effects in Structural Equation Models,"

Sociological Methodology, vol. 13, no. 1982, p. 290, 1982.

[35] N. M. Sunarsih and N. P. Y. Mendra, "Pengaruh Modal Intelektual terhadap Nilai Perusahaan dengan Kinerja Keuangan sebagai Variabel Intervening pada Perusahaan yang Terdaftar Di Bursa Efek Indonesia," in Seminar Nasional Akuntansi, 2012.

[36] N. Yunita, "Pengaruh Modal Intelektual terhadap Kinerja Keuangan dan Nilai Pasar," Accounting Analysis Journal, vol. 1, no. 1, pp. 1-7, 2012. 